\title{
The influence of Stakeholder management on the success of Social Development Projects within a higher education institution: A case study.
}

\author{
Jennifer Catheryne Fuentes Díaz ${ }^{1}$, Fabián David Güiza Pinzón ${ }^{1 *}$ \\ ${ }^{1}$ Faculty of Engineering, Universidad EAN, Bogotá- Colombia
}

\begin{abstract}
.
In Colombia, Higher Education institutions such as universities, both public and private, must fulfil three core functions: Education, Research and Social Development. Social Development refers to the services carried out by the university that make a positive impact on the surrounding communities and improve social welfare. This is achieved through teaching and research, which generate a range of projects that directly connect an institution to those communities. The stakeholders for Social Development projects typically have a significant influence on their development and success, however the relationship between stakeholder management and a project's success has been poorly documented to date. This article seeks to describe the characteristics of this relationship and establish the importance of stakeholder management in the context of Social Development projects, using the institution of the University of Boyacá as a case study. Through a literature review and data analysis, this study will consider the research variables in order to determine the influential stakeholder groups in Social Development projects and, furthermore, define how the management of stakeholders positively affects their success. By doing so, we aim to generate literary support for future research and investigation in this area of projects.
\end{abstract}

Keywords: stakeholder management, success, Social Development projects, universities, stakeholder management influence.

\section{Introduction}

In our study, we apply terms such as project management and stakeholder management that are more typically associated with the construction and engineering sectors, to discuss their influence in Social Development projects. Good project management, as well as stakeholder management, has become essential to the better implementation and operation of projects, regardless of the sector where they are carried out. Better project management implies a direct compliance with particular requirements that offer solutions to problems, or that generate value for clients and/or stakeholders, who are the ultimate beneficiaries of their implementation. This compliance can be categorized as successful when variables such as scope, schedule, and costs are met, according to the theorical support demonstrated in this study. 


\title{
$6^{\text {th }}$ International Conference On Opportunities and Challenges In MANAGEMENT, ECONOMICS and ACCOUNTING
}

\author{
18 - 20 September , $2020 \quad$ Milan, Italy
}

Amongst the various projects generated by the case study arise those that fall within the Social Development function associated with the interactions between the University and the social environment and communities where it is situated. These projects that are carried out as part of the function of Social Development within the university context have a strong academicinvestigative focus, where project management is practically unknown in their implementation (Fuentes \& Guiza, 2020). Universities or higher education institutions in Colombia are required to fulfil three main functions: Education, Research and Social Development. These are each evaluated by the Ministry of Education and The University's fulfillment of these social community-related aspects affect national and international accreditation processes, access to student financing, and other metrics used to value these institutions. These projects which are the focus of our study have a strong social component, due to the specific involvement of communities in their development, and the expectation that they fulfil the third function of the university's Social Development aspect. Consequently, in the development and importance of these activities, a knowledge or an awareness of the relevance of stakeholder management is required and an understanding of how it influences the success of these Social Development projects. The main objective of this research is to establish the relation between these elements of Social Development projects.

With this purpose of establishing a clear relationship, it was necessary to create an instrument for analysis and collection of data related to the influence of stakeholders in the success of Social Development projects. According to Davis, there is not a previous method that performs this type of analysis (Davis, 2017). Furthermore, it is necessary to know how this process of analysis occurs within the case study concerning stakeholder management, in order to generate best practices in the future management of this type of project. According to the literature review, stakeholder management is mostly related to types of industries (such as construction) and projects, as are definitions of success and their interrelation; however, these are neither directly relevant or applied to Social Development projects. Most literature refers to the variables independently as well. In addition, the analysis of data collected through this instrument will provide not only a better understanding of these projects but also literary support for better general practices. In studying the approaches to this kind of project, a general lack of project and stakeholder management practices is observed, as is supporting evidence of their success.

\section{Methodology}

The present work has a quantitative approach, which aims to establish the relationship between the influence of stakeholder management on the success of projects developed at the level of Social Development at the University of Boyacá. It is also descriptive and correlational. According to Hernández et al. (1997), descriptive studies seek to specify the essential properties of people, groups, communities, or any other phenomenon subjected to analysis. Further to this, Hernandez suggests that correlational studies have the purpose of measuring the degree of relationship that exists between two or more concepts or variables (Hernández et al., 2014). 


\section{$6^{\text {th }}$ International Conference On Opportunities and Challenges In MANAGEMENT, ECONOMICS and ACCOUNTING}

18 - 20 September , $2020 \quad$ Milan, Italy

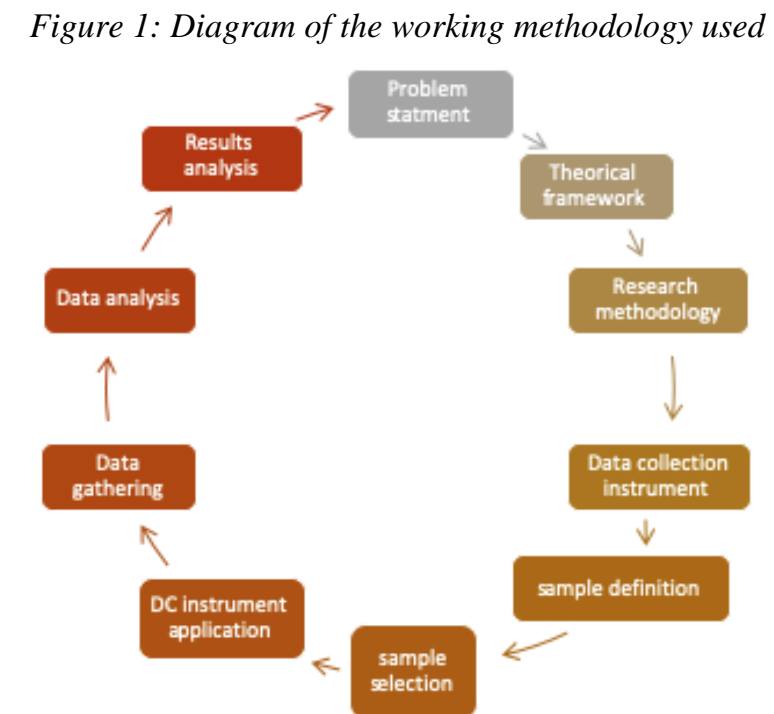

Source: Own elaboration based on qualitative research Hernández, Fernández y Baptista (2014)

The information collection instrument was applied to the number of the simple random sample given for the population of active-internal stakeholders: Project Managers. The total Social Development projects at the time of implementation were 85, where the Project Managers were the sample. The formula is known as a non-probabilistic intentional sampling of the structural type applied (Torres, 2008), and the instrument applied to 69 of the interested parties previously mentioned, in order to interpret the data to be measured $95 \%$ of the time. Being in the interval of $\pm 5 \%$ to the data observed in the survey.

\subsection{Analysis of the study area}

The University of Boyacá, the case study for this investigation, is one of the three hundred and forty-seven (347) Higher Education Institutions (HEI) in the country. These HEI have around 2.293.550 students, 149.280 professors, and an un-estimated number of other workforces. together, these institutions generate $2 \%$ of the country's Gross Domestic Product (GDP). (Ministerio Educacion Nacional, 2016). This institution alone in 2019 carried out 85 Social Development Projects (SPP), performed in several surrounded communities with different kinds of needs.

\subsection{Obtention and evaluation of business sample}

The following formula was applied, (Torres, 2008):

$$
n=\frac{N *(Z)^{2} * P *(1-P)}{(N-1) * e^{2}+Z^{2} * P *(1-P)}
$$

Based on the above, the result of the necessary representative sample with $95 \%$ confidence corresponds to 69 stakeholders. These were the different roles identified related to the sample: 


\title{
$6^{\text {th }}$ International Conference On Opportunities and Challenges In MANAGEMENT, ECONOMICS and ACCOUNTING
}

\author{
18 - 20 September , $2020 \quad$ Milan, Italy
}

Social Development Coordinator 9.0\%; Executor 76.1\%; Advisor 13.4\%; Social Development Committee $1.5 \%$. Wherein most roles are made up of teachers $65,7 \%$, then students $29,9 \%$, and general stakeholders at $1,5 \%$. The case study as a Higher Education Institution is mostly considered a functional organization with $71,6 \%$ of activities fulfilling a functional purpose; this means that it organized by departments or areas where, alongside the usual academic activities developed, they oversee the project's responsibilities.

\section{Theorical support}

\subsection{Stakeholders management analysis}

There are several evaluations of stakeholder management practices dating from 1991 to nowadays, but according to (Samboni \& Blanco, 2015), there is no standard tool or methodology to carry out stakeholder management and neither for Social Development Projects. According to the Project Management Institute, the management of stakeholders involves identifying people, groups or organizations that may affect or be affected by the development of the project, in order to analyze their expectations and the likely impact they will have within the project. In turn, this helps to develop appropriate management strategies with the intention of achieving the active participation of these people in decisions, in the execution of the project and thus improve their level of satisfaction (Project Management Institute, 2017).

The purpose of stakeholder analysis tools is to identify the stakeholders within a project, characterize them, and use this information to implement active management initiatives (Bourne \& Weaver, 2010). This identification determines who are the stakeholders, their influence on the development of the project, the obstacles generated, or their integration, in order to establish strategies for the adequate achievement of the objectives of any organization or project. The use of these comprehensive and useful measures developed take into account the relevant stakeholder groups and their interests. This relevance of stakeholders becomes a prerequisite for successful stakeholder management (Rowlinson \& Cheung, 2008); therefore, it becomes a result of successful projects, especially those considered to be complex (McElroy \& Mills, 2000). Stakeholder management involves the project team and enables stakeholders to identify, negotiate, and achieve objectives through participation in the project process (Rowlinson \& Cheung, 2008).

Before 2000, there was no discussion of stakeholder management in terms of project management, (McElroy, 2000 cited in Turner, 2000). Particularly in the education sector, this area of knowledge is an unknown field when projects retain an academic and investigative focus. Investigation of the relationship of stakeholders, their management, and their impact on success in projects of Social Development is even more scarce. Up to the moment of the present investigation, it has not been possible to find or relate a single reference related to these variables, and specific to this type of project. As a consequence, this research aims to answer a particular need through the following research question: To what extent does stakeholder management influence the success of Social Development projects? Moreover, understanding 


\title{
$6^{\text {th }}$ International Conference On Opportunities and Challenges In MANAGEMENT, ECONOMICS and ACCOUNTING
}

\author{
18 - 20 September , 2020 Milan, Italy
}

the influence of stakeholder management on the success of these Social Developments projects also involves answering a second research question: Who are the main stakeholders in Social Developments projects, and what is their level of influence? By knowing these stakeholders, their roles and correlations, and current practices within the Higher Education sector, will not only generate literary support in this field, but it is also an opportunity to improve existing practices, thus obtaining more effective results that, within the social, community-driven aspects, will be of high relevance, especially in these times of complexity and turbulence faced by Higher Education institutions both locally and globally.

In this sense, and corresponding to the existing literature, it becomes necessary to establish a definition of stakeholder management to this specific type of project as follows. Garcia et al states: "Stakeholder management is an important activity in the development of the project since they, the stakeholders, are decisive for governance (García et al., 2018); Without proper management, the stakeholders tend to lose interest, reducing their availability and attitude for the development of the programmed activities of the project (Junior et al., 2015) leading to a perception of failure. On the contrary, if well-managed stakeholders, within the organization and the project managers, a premise of consented success is built (Bourne \& Walker, 2005). Likewise, stakeholder management is the constant development of relationships with stakeholders for the success of the project (McElroy \& Mills, 2000) in the different project life cycles to obtain successful results (Assudani \& Kloppenborg, 2010)."

\subsection{Project stakeholder management and success relation.}

Success in projects is grouped into 4 main stages. See table No. 1. In this same relation, several authors have proposed their definitions of success.

Table 1: success characterization stages

\begin{tabular}{|l|l|l|}
\hline & \multicolumn{1}{|c|}{ period } & \multicolumn{1}{c|}{ Success characterization } \\
\hline stage 1 & $1960-1980$ & $\begin{array}{l}\text { Project implementation and delivery: Metrics such as time, cost, and specifications } \\
\text { were prevalent for measuring project success. The customer contact was minimal. } \\
\text { Literature and practice from this period predominantly supported this trial as the } \\
\text { foundation of project management. }\end{array}$ \\
\hline stage 2 & $1980-1990$ & $\begin{array}{l}\text { Critical Success Factors (CSF): Lists of factors that were the source to estimate } \\
\text { the success of projects were identified and created, however, these factors were } \\
\text { not standardized, grouped, or conceptualized based on the project scenario (Judgev } \\
\text { \& Müller, 2005). }\end{array}$ \\
\hline stage 3 & $1990-2000$ & $\begin{array}{l}\text { Reference Frames of Critical Success Factors (CSF): In this period, reference } \\
\text { frames regarding the success of projects emerge. After this period, most } \\
\text { publications took the concept that success was dependent on the stakeholders } \\
\text { (Lester, 1998 cited in Judgev \& Müller, 2005). }\end{array}$ \\
\hline
\end{tabular}




\title{
$6^{\text {th }}$ International Conference On Opportunities and Challenges In MANAGEMENT, ECONOMICS and ACCOUNTING
}

\author{
18 - 20 September , $2020 \quad$ Milan, Italy
}

\begin{tabular}{|l|l|l|}
\hline \multicolumn{1}{|c|}{ period } & \multicolumn{1}{c|}{ Success characterization } \\
\hline stage 4 & $\begin{array}{l}2000- \\
\text { onwards }\end{array}$ & $\begin{array}{l}\text { Strategic project management: Most of the literature from this period highlights } \\
\text { four conditions for project success: 1. Success criteria agreed with stakeholders. } \\
\text { 2. Collaborative work relationships. 3. The project manager must empower with } \\
\text { flexibility. 4. The owner (sponsor) must take an interest in the performance of the } \\
\text { project. }\end{array}$ \\
\hline
\end{tabular}

Source: Own elaboration with information of (Jugdev \& Müller, 2005).

The Social Development Projects, according to the case study, are mainly driven by four indicators: management, result or effect, process or accomplishment, and (positive) impact. These indicators do not relate to or demonstrate stakeholder management, nor its influence on the success of the project. In an investigation carried out by Thomson, taking into account the performance metrics of a project based on the value judgment of the clients, it was shown that the stakeholders declared that their needs were not taken into account and, as a result, that the project was considered a failure (Thomson, 2011). In this order of ideas, projects of Social Development must arise from the attention of the needs of the interested parties, not starting exclusively from the criteria of the executors, nor limiting these efforts only to initial stages of the project. In the words of (Serrador \& Turner, 2014), it is necessary that success criteria are agreed among the interested parties before the project start and that these conditions are accomplished in order to achieve success; however, these criteria alone do not guarantee it.

However, until the date of this review, there has not been a registered model in the project management literature focused on stakeholders and their relationship to project success (Davis, 2017). Currently, the success criteria of the projects are measured using multiple parameters; These include the realization of strategic objectives focused on the client, the satisfaction of the end-user, and the satisfaction of other stakeholders. (Ika, 2009) in (Assudani \& Kloppenborg, 2010). The stakeholders are the best judges of the success of the projects in (Serrador and Turner, 2014) by (Turner \& Zolin, 2012), and this perception of success evaluated with dependence over time. Shortly after project completion, time, scope, and cost relationships are no longer relevant, the impact on the customer and their satisfaction become more critical than the standard measures. (Shenhar et al., 1997) in (Serrador \& Turner, 2014).

The traditional measurements of the projects are based on the relations of the iron triangle: scope, time and cost (Atkinson, 1999) in (Serrador \& Turner, 2014), but in Social Development projects, these measurements of the triangle are not appropriate for measuring, since the projects are initiated with substantial restrictions of all three variables of cost, scope and time, and that most of them arise without a proper project management methodology. Nevertheless, despite these restrictions and lack, as established by Munns and (Bjeirmi,1996) in (Serrador \& Turner, 2014), the projects can be successful. Attending to (Munns \& Bjeirmi, 1996) in (Serrador \& Turner, 2014), "The projects end when delivered to the clients." However, in Social Development projects, the project does not work in this scenario, on the contrary, the project can only start if there is a client who benefits from the work, but who must work on it to be 


\section{$6^{\text {th }}$ International Conference On Opportunities and Challenges In MANAGEMENT, ECONOMICS and ACCOUNTING}

\section{8 - 20 September , 2020 Milan, Italy}

completed and obtain the proposed benefits; According to this statement, stakeholder management is essential for their success.

For this reason, the need arises to define success according to what (Cooke-Davies, 2002) has stated as "project success" concerning the fulfillment of the objectives, and not "project management success," which follows traditional measures of scope, time and cost performance. Based on this argument, the definition of success in Social Development projects depends on the achievement of the project objectives, which tends to align with the objectives in the framework of the University Social Responsibility policy RSU, in the guidelines of projects of Social Development of the institution. Likewise, it is clear that for any other university and Social Development project, they will be those stipulated in the institution's internal policies and guidelines. This investigation measured it in terms of the perception of the stakeholders regarding the fulfillment of the objectives of the project.

\subsection{Stakeholders.}

Our definition of stakeholders is based on the characterizations of stakeholders made in different literature reviews, carried out by (Li, 2007) adapted by (Rowlinson \& Cheung, 2008), which covers 21 years of characterizations of keys organizational stakeholders. The most aligned and suitable for Social Development Projects correspond to the discrimination of independent characteristics made by (Rowlinson \& Cheung, 2008) and (Kloppenborg, 2009), which distinguish between internal and external stakeholders. PMI and other authors also adopt these. However, in a better understanding of this kind of project, the authors of this research propose an additional category of classification that works explicitly for Social Development projects. In addition to the classification of Internal and External stakeholders, it is also recommended to classify stakeholders into two more groups, as either "Active" and "Passive". Active, those who must be directly involved with the development and/or implantation of the and without whose contribution, interest, and attitude, the deliverables of this type of project cannot materialize. The Active Stakeholders Characterized in this study are: teachers, researchers, students, and members of the community who need to solve problems (by means of the project) that directly affect their quality of life. Passive Stakeholders, on the other hand, are those who may or may not be involved in the development of the project - and therefore the materialization of the deliverables may occur without their involvement - but who have enough power within its initial and final execution, influencing the determination of the project as successful or not. The Passive Stakeholders Characterized here are: administrative staff, assessment committee of Social Development projects, graduates from the University, communities, groups of people that need to solve their problems that may affect their quality of life, however either their needs were not identified or appropriately managed, or the project in which they are involved does not directly generate their interest or meet their expectations, and governmental and non-governmental entities. Classifications of Internal, External, and Active, Passive stakeholders, in agreement with the descriptions of these categories, emerge from the theoretical review of this research and the understanding which results from the analysis and experiences of the authors in the management of Social Development Projects. 


\title{
$6^{\text {th }}$ International Conference On Opportunities and Challenges In MANAGEMENT, ECONOMICS and ACCOUNTING
}

\author{
18 - 20 September , 2020 Milan, Italy
}

\section{Results.}

The four leading roles characterized as Key Stakeholders in Social Development Projects are teachers $(65,7)$, students $(29,9 \%)$, staff $(3,0 \%)$, and communities $(1,5 \%)$ validated with the sample. In the same way, the categorization of Internal $(85,1 \%)$, external $(13,4 \%)$ with broad theoretical support was confirmed. Concerning Active $(89,1 \%)$ and Passive $(10,4 \%)$ stakeholders, the sample was also able to discriminate between them by validating the new categorization for stakeholders in Social Development Projects. Even the contrast between the stakeholder categorization matches in the range of $+-5 \%$ of reliability.

\subsection{Result in terms of stakeholder management.}

In an overview about the general processes carried out in stakeholder management practices, stakeholder identification management is mostly developed at $76,1 \%$; Plan Stakeholder management at $78,2 \%$; the stakeholder engagement management at $86,4 \%$, and Stakeholder involvement monitoring at $86,7 \%$.

Figure 3. Stakeholder management in Social Development Projects

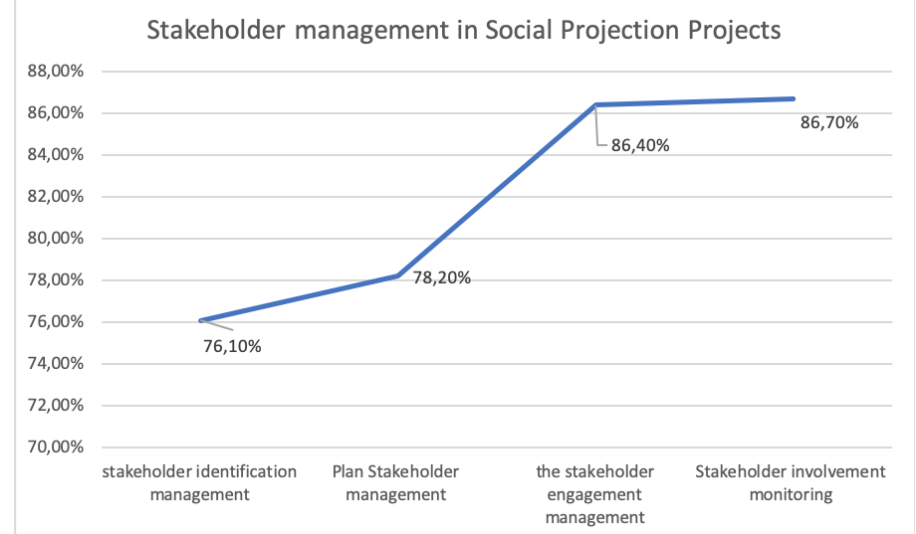

Source: Own elaboration

The analysis also shows with lower implementation the use and updating of tools and techniques in this first process of identification of stakeholders, roughly between $14,9 \%$ and $16,4 \%$. Even though it is observed that the identification process was carried out, however, the use of formal tools and techniques was not methodic or a standard practice. Regarding the Plan Stakeholder management, the lowest rates ranged from 7,6 to $19,7 \%$ related to stakeholder mapping. In this mapping, the stakeholders are placed into categories as a representation technique to plan future management. Following Engagement Management, processes as question and doubts solving 55,2\%, and enhancing positive stakeholders' commitment to the project, $53,7 \%$ were likely positive. Instead, the establishment of communication methods at $20,9 \%$, risk management at $19,6 \%$, and feedback at $17,0 \%$ these processes were the least noticed. Concerning Monitor Stakeholder Engagement, the Project Manager played a vital role at 52,2\% assuming conflict management attitudes toward conflict solving, also looking ahead to the accomplishment of stakeholders' interest and expectations at 49,3\%. On the contrary, the 


\section{$6^{\text {th }}$ International Conference On Opportunities and Challenges In MANAGEMENT, ECONOMICS and ACCOUNTING}

\section{8 - 20 September , 2020 Milan, Italy}

lesson learned $17,9 \%$ of the overall processes, and a periodic assessment of stakeholders' engagement desired against planned at $22,0 \%$ were the lowest performed activities.

Figure 3. Stakeholder correlation result analysis - kruskell-wallis

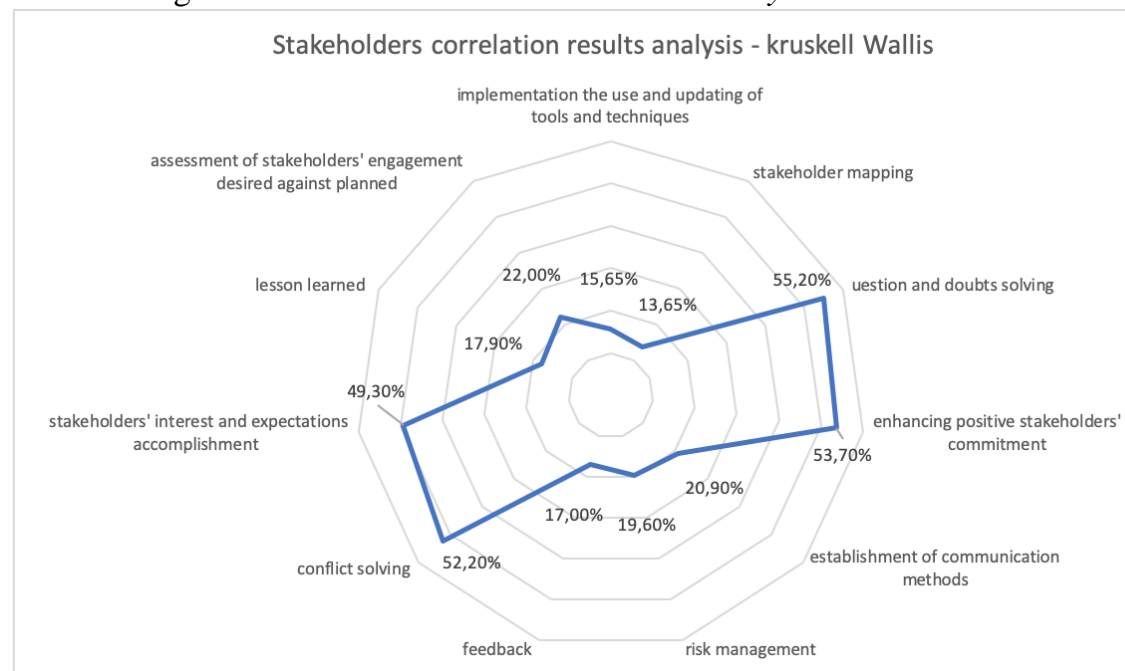

Source: Own elaboration

\subsection{Results in terms of success perception in the Social Development Projects.}

In an overall view, $88,4 \%$ of Project Managers considered that this kind of project developed from a success perspective with $59,7 \%$ conducted in line with Social Development objectives accomplishment, and at 55,2\% corresponding to quality requirements. General results satisfaction at the culmination of the projects was around 53,0\%. However, only $12,1 \%$ of this satisfaction was backed by a tool or measurement technique. Even though these projects started with high restrictions on cost, time, and scope, the sample considered that these projects mostly accomplished goals to schedule at $47,8 \%$ and $59,7 \%$ concerning planned cost. On the other hand, $26,7 \%$ considered that risk management was not adequate in their projects. Also, a general misunderstanding on this matter was evident relating risk to other aspects apart from the project. Neither was there evident use of Earned Value or Schedule Value or other measures to monitor and control projects along with their development.

\subsection{Stakeholder Management influence in Social Development Project Success.}

In addition to the previous analysis, a Spearman correlation was implemented to validate the relationship between the variables where all four aspects of the Stakeholder Management (stakeholder identification, plan stakeholder management, stakeholder engagement management, and Stakeholder involvement monitoring) relates in a positive and significant way to the success of Social Development Projects. In a specific view of the correlation between all four aspects of the stakeholder management, they are linked to a weak or deficient initial stakeholder identification, a lower perception of success in this kind of project. The low usage of identification tools and techniques is evident again in this correlation, observing their influence in the project's success. This success is strongly related to stakeholders' needs and 


\title{
$6^{\text {th }}$ International Conference On Opportunities and Challenges In MANAGEMENT, ECONOMICS and ACCOUNTING
}

\author{
$18-20$ September , $2020 \quad$ Milan, Italy
}

requirement accomplishment without avoiding the overarching Social Development goals. It establishes that this success could be strongly affected by the lack of stakeholder knowledge and the use of visual representations, therefore consisting of a lack of engagement and understanding of their involvement in the project.

Proper Stakeholder involvement in the development of the project has a stable incidence at the project's success. This process is relevant because it is mostly related to the people and team development, through the use of communication management where the overall process does not require proper use of tools and techniques. The lack of a standard definition of the project's objectives by stakeholders has a strong influence on the project's success and how the stakeholders measure it. The above supports that Social Development projects must arise from the attention of the needs of the interested parties that do not stand exclusively in the criteria of the project manager or limiting these efforts only to the initial stages of the project. Additionally, the involvement focused on maintaining the commitment of the interested parties is relevant to the success of a project, especially in these social projects where without the involvement of external-active stakeholders, i.e. "communities", these projects would simply not have a reason to exist; but, without their positive participation, the project could not generate the expected results for those involved, both executors and communities.

The lack of monitoring in the involvement of the interested parties and neglection of the experiences, both positive and negative, of previous projects for the planning and development of new ones, can also affect how the project can be successful. Likewise, the management of stakeholder monitoring affects the results generated in meeting the established needs and requirements. In this same way, they influence the fulfillment of the objectives of Social Development. Activities related to monitoring, like those of the engagement management process, were characterized by the non-preferential use of tools and techniques, which require prior knowledge by managers for their use and implementation, which in this case affected the correlations positively.

\section{Conclusion}

Due to the lack of previous literature related to Social Development projects and their stakeholders, the proposed characterizations for the critical stakeholders in these projects were verified and validated, with strong bibliographical support. Amongst these, we identified internal and external classifications, which can also be defined as "Active" and "Passive", according to the stakeholder's role in the project. Likewise, the definition made for stakeholder management and the success in this type of project is appropriate in order to provide a more general context for the management of projects within Social Development. The collated results and data allow a better understanding of both stakeholder management and project management in these types of project. Particularly in the case of Social Development in Higher Institutions, Project Management has been scarcely documented, therefore this information accomplishes one of the objectives related to stakeholder characterization and also provides theorical support 


\title{
$6^{\text {th }}$ International Conference On Opportunities and Challenges In MANAGEMENT, ECONOMICS and ACCOUNTING
}

\author{
$18-20$ September , $2020 \quad$ Milan, Italy
}

for future investigation and likewise for successful stakeholder management in this type of projects.

With the analysis carried out through the use of the SPSS statistical tool, linking the results and findings for the management of stakeholders and the perception of success, it was possible to illustrate the proportionality of these two variables, and that they are most significantly and positively correlated for Social Development projects as previously described. In other words, the influence of the groups of stakeholders on the success of the projects is closely related. As such, the main objective of this study to identify this relationship was accomplished. Moreover, how these factors are managed will largely depend on their successful completion; Social Development projects should not only focus on economic issues, schedule or scope; their primary function, in fact, for which they are implemented, yet of which little is taken into account, is the generation of value for their active and passive stakeholders.

This research indicates that the management of the interested parties plays a large part in the success of the projects, as stated by (McElroy \& Mills, 2000), however it was also evident in the case study that there is a predominant non-use of tools and techniques for identifying the stakeholders. Even if the management of the interested parties is not entirely structured in the use of tools and techniques, it is equally significant in the success of the projects. In the analysis made, opportunities for improvement were suggested to be implemented by the case study. Apart from the definition of success outlined for these Social Development Projects, it is also relevant that the criteria for success must be defined among the stakeholders before the project begins and that these conditions must be met to achieve success as stated by (Serrador \&Turner, 2014). This recommendation must be considered as a fundamental element to guarantee success.

On the other hand, concerning a definition of success, this depends on how managers conceive of their projects as successful; however, these evaluations by the different groups of stakeholders were not available, confirming the statement of (Turner \& Zolin, 2012) that the evaluation of success in different interested groups is rarely performed. The bibliographic evaluation carried out around the research of stakeholders in Social Development Projects is limited to adequately describe those interested in Social Development projects and the roles interacting. Consequently, it is necessary to generate new points of view around the classification of interested parties; in this manner, this article allows us to provide an additional bibliographic source that will open the way for future research on this topic.

\section{References}

[1] Aragonés-Beltrán, P., García-Melón, M., \& Montesinos-Valera, J., (2017). How to assess stakeholders' influence on project management? A proposal based on the Analytic Network Process. International Journal of Project Management, 35(3), pp. 451-462.

[2] Assudani R, Kloppenborg T (2010) Managing Stakeholders for Project Management Success: An Emergent Model of Stakeholders. Journal of General Management 36(1), 67-80. 


\title{
$6^{\text {th }}$ International Conference On Opportunities and Challenges In MANAGEMENT, ECONOMICS and ACCOUNTING
}

\author{
18 - 20 September , 2020 Milan, Italy
}

[3] Bourne, L. y Walker, D. (2005), Visualising y mapping stakeholder influence, Management Decision, Vol. 43 No. 5, pp. 649-660.

[4] Bourne, L., \& Weaver, P. (2010). Mapping Stakeholders. En E. Chinandio, \& P. Olomolaiye, Construction Stakeholders Management, pp. 99-120 Willey-Blackwell.

[5] Bourne, L. (2013). Gestión de Stakeholders: Gestión de grupos de interés. Ediciones EAN, Bogotá.

[6] Cervantes V (2005), interpretations of the alpha coefficient of cronbach, Universidad Nacional de Colombia, Bogotá.

[7] Cooke-Davies, T (2002) The "real" success factors on projects. International Journal of Project Management 20, pp 185-190

[8] Creswell, J. W. (2014). Research Design: Qualitative, Quantitative, y mixed Methods Approaches. Sage Publications. 4th edition. Los Angeles.

[9] Davis, K. (2017). An empirical investigation into different stakeholder groups' perceptions of project success. International Journal of Project Management 35, pp. 604-617.

[10] García A, Serna D, Santos W. (2018). Análisis de los interesados sobre el desempeño exitoso de los proyectos. Revista Espacios. Vol. 39 ( No 51) Año 2018. pp 16.

[11] Hair, J., Black, W.C., Barry, J. y Anderson, R.R. (2010). Multivariate Data Analysis. Prentice-Hall. New York.

[12] Hernández Sampieri, R; Fernández Collado, C; Baptista Lucio, M. (1997). Metodología de la investigación. México DF, México: Mc Graw Hill. [online] Available:

https://www.slideshare.net/albescas/metodologa-de-la-investigacin-hernndez-sampieri-8385385 [13] Hernández Sampieri, R; Fernández Collado, C; Baptista Lucio, M. (2014). Metodología de la investigación. Mc Graw Hill. México DF, México.

[14] Jepsen, A.L.; Eskerod, P. (2009) Stakeholder analysis in projects: Challenges in using current guidelines in the real world. International Journal of Project Management, 27, pp. 335343.

[15] Jugdev, K.; Müller, R. (2005) A restrospective look at our evlolving undestanding of project success. Project Management Journal, 36 (4). Pp. 19-31.

[16] Júnior, A. C. P., Porto, G. S., Pacífico, O., \& Salgado Júnior, A. P. (2015). Project Stakeholder Management: A Case Study of a Brazilian Science Park. Journal of Technology Management \& Innovation, 10(2), pp. 39-49.

[17] Kloppenborg, T. J. (2009). Project management: A contemporary approach. SouthWestern Cengage Learning. Mason, $\mathrm{OH}$.

[18] McElroy, B.; Mills, C. (2000). Managing stakeholders. In Gower Hybook of Project Management; Turner, R.J., Simister, S.J., Eds.; Gower: Aldershot, U.K.

[19] Ministerio de Educación Nacional, (2016). Compendio Estadístico Educación Superior Colombiana. Imprenta Nacional de Colombia, Bogotá.

[20] Missonier, S., Loufrani-Fedida, S. (2014). Stakeholder analysis y engagement in projects: from stakeholder relational perspective to stakeholder relational ontology. International Journal of Project Management. 32 (7), pp. 1108-1122.

[21] Mulcahy, R, PMP \& otros (2018) PMP preparation exam, novena edición. RMC Publications, Inc TM.

[22] Netquest (2019), sample calculator, [online] Available:

https://www.netquest.com/es/gracias-calculadora-muestra?submissionGuid=2778d71f-bc4b-4aeaa1cb-88e1c2504ade 


\title{
$6^{\text {th }}$ International Conference On Opportunities and Challenges In MANAGEMENT, ECONOMICS and ACCOUNTING
}

\author{
18 - 20 September , $2020 \quad$ Milan, Italy
}

[23] Project Management Institute. (2017). A guide to the project management body of knowledge (PMBOK guide). Project Management Institute. Newtown Square, Pa.

[24] Rowlinson, S. \& Cheung, Y. K. F. (2008). Stakeholder management through empowerment: modeling project success. Construction Management y Economics, 26, pp. 611623. DOI:10.1080/01446190802071182.

[25] Samboni, A, Blanco, J, (2015). Herramientas de gestión de interesados utilizadas en las etapas de planeación y control de proyectos. Universidad de San Buenaventura. Santiago de Cali, Valle del Cauca. Colombia

[26] Serrador, P, Turner, R (2014) The Relationship between Project Success and Project Efficiency. Procedia - Social and Behavioral Sciences 119, pp. $75-84$.

[27] Thomson Dereck (2011) A pilot study of client complexity, emergent requirements y stakeholder perceptions of project success, Construction Management y Economics, 29:1, pp. 6982.

[28] Torres, R. (2008) Aplicación de instrumentos de Relaciones Públicas en el ámbito del Desarrollo Local Descripción y posibilidades. Universidad autónoma de Barcelona. [online] Available: http://www.rrppnet.com.ar/relacionespublicasydesarrollolocal.pdf

[29] Turner, R. (2000). Managing stakeholders. In Gower Hybook of Project Management; Turner, R.J., Simister, S.J., Eds.; Gower: Aldershot, U.K.

[30] Turner, R., Zolin, R. (2012) Forecasting succes on large projects: Developing reliable scales to predict multiple perspectives by multiple stakeholders over multiple time frames. Project Management Journal, 43 (5).

[31] Universidad de Boyacá, (2018) Documentos institucionales Rectoría Serie 2 No. 5, Política de Responsabilidad Social Universitaria. Universidad de Boyacá. 2018

[32] Vallaeys, F., (2009). ¿Qué es la Responsabilidad Social Universitaria? Pontificia Universidad Católica del Perú. [online] Available:

http://www.ciens.ucv.ve/ciens/servicio_comunitario/documentos/rsu.pdf

[33] Vallaeys, F. (2010). Breve marco teórico de responsabilidad social universitaria. Breve marco teórico de responsabilidad social universitaria. [online] Available:

http://rsuniversitaria.org/web/images/stories/BreveMarcoTeodelaResponsabilidadSocialUniv.pdf [34] Voropaev, V., Gelrud, Y., \& Klimenko, O. (2016). Who Manages What? Project Management for Different Stakeholders. Procedia - Social and Behavioral Sciences, 226, pp. 478-485. [online] Available: https://doi.org/10.1016/j.sbspro.2016.06.214 